\title{
Peer Review of "Early Experience With Neutralizing Monoclonal Antibody Therapy for COVID-19: Retrospective Cohort Survival Analysis and Descriptive Study"
}

\section{Anonymous}

\section{Related Articles:}

Preprint (medRxiv): https://www.medrxiv.org/content/10.1101/2021.04.09.21255219v1

Preprint (JMIR Preprints): https://preprints.jmir.org/preprint/29638

Authors' Response to Peer-Review Reports: https://med.jmirx.org/2021/3/e33496/

Published Article: https://med.jmirx.org/2021/3/e29638/

(JMIRx Med 2021;2(3):e33499) doi: 10.2196/33499

\section{KEYWORDS}

infectious disease; monoclonal antibody therapy; COVID-19; experience; therapy; drug; patient outcome; risk; efficacy; approach; treatment; pandemic; antibody; immunotherapy; immune therapy

This is a peer-review report submitted for the paper "Early Experience With Neutralizing Monoclonal Antibody Therapy for COVID-19: Retrospective Cohort Survival Analysis and Descriptive Study."

\section{Round 1 Review}

\section{General Comments}

In this paper [1], the authors study the effect of monoclonal antibodies and their benefit in patients with COVID-19. The authors conclude that, although this therapy may be an important treatment option for early mild to moderate COVID-19 in patients at high risk, further investigations are needed to define the optimal timing of monoclonal antibody treatment to reduce hospitalization and mortality.
Although this topic is not entirely new, the paper looks good to me and confirms other previously published data.

\section{Specific Comments}

As Tables 1 and 2 are quite complex, they need a clear legend and not just the title, as reported.

For greater clarity, the figures should also be better explained.

In the Introduction and Discussion when talking about COVID-19, for the sake of clarity, we need to better explain the inflammation that kills people and not just go straight to the monoclonal antibodies. Therefore, to make this paper more interesting for the readers of this important journal, the authors should expand the discussion on this subject a little to give a wider view to the reader.

\section{Conflicts of Interest}

None declared.

\section{Reference}

1. Jarrett M, Licht W, Bock K, Brown Z, Hirsch J, Coppa K, et al. Early experience with neutralizing monoclonal antibody therapy for COVID-19: retrospective cohort survival analysis and descriptive study. JMIRx Med 2021 Sep;2(3):e29638 [FREE Full text]

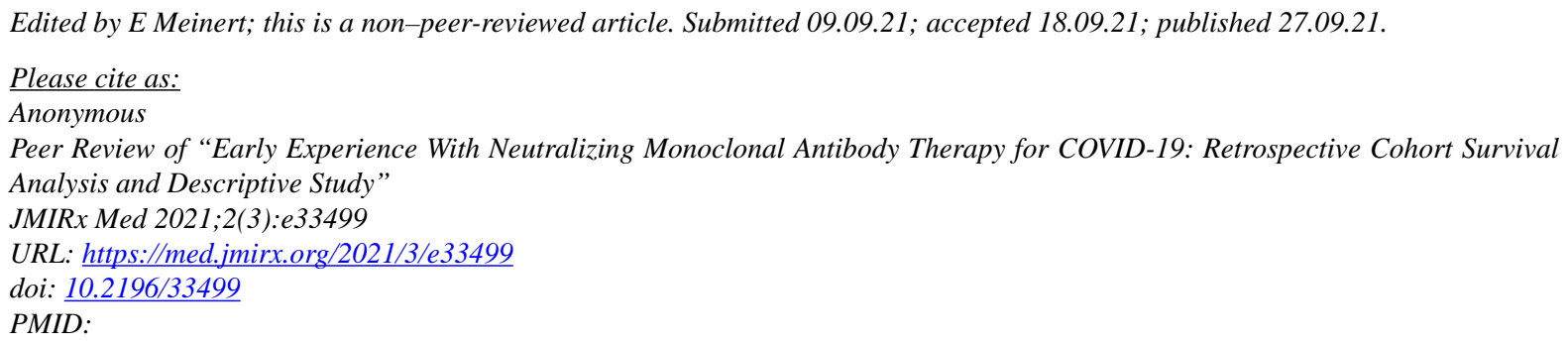




\section{JMIRx Med}

(C) Anonymous. Originally published in JMIRx Med (https://med.jmirx.org), 27.09.2021. This is an open-access article distributed under the terms of the Creative Commons Attribution License (https://creativecommons.org/licenses/by/4.0/), which permits unrestricted use, distribution, and reproduction in any medium, provided the original work, first published in JMIRx Med, is properly cited. The complete bibliographic information, a link to the original publication on https://med.jmirx.org/, as well as this copyright and license information must be included. 